\title{
The effect of cigarette smoke on fertilization and pre-implantation development: assessment using animal models, clinical data, and stem cells
}

\author{
Prue Talbot and Sabrina Lin \\ Department of Cell Biology and Neuroscience, Cell Molecular and Developmental Biology Graduate Program, UCR Center for Stem Cell Biology, University of \\ California, Riverside, California, USA
}

\begin{abstract}
Numerous studies have repeatedly shown that women who smoke experience problems establishing and maintaining pregnancies, and recent work has further demonstrated that the in utero effects of smoke may not be manifested until months or even years after birth. The purpose of this review is to examine the recent literature dealing with the effects of cigarette smoke on the earliest stages of human prenatal development. Studies in this area have included the use of animal models, patients undergoing in vitro fertilization, and embryonic stem cell models. Events leading to fertilization, such as cumulus expansion, hyperactivation of sperm motility, and oocyte pick-up by the oviduct are all impaired by smoke exposure in animal models. Steps crucial to fertilization such as the acrosome reaction and sperm binding to the zona pellucida are likewise inhibited by cigarette smoke. Preimplantation embryos and stem cells that model embryos show a number of adverse responses to smoke exposure, including poor adhesion to extracellular matrices, diminished survival and proliferation, and increased apoptosis. The current literature demonstrates that the earliest stages of prenatal development are sensitive to smoke exposure and indicates that pregnant women should be advised not to smoke during this time.
\end{abstract}

Key words: cigarette smoke, embryos, fertilization, IVF, stem cells, toxicology.

\section{INTRODUCTION}

Two general classes of cigarette smoke exist. Mainstream smoke (MS) is the puff of smoke inhaled by active smokers, while sidestream (SS) smoke burns off the end of cigarettes and is inhaled by passive smokers. SS smoke, which is the major component of environmental tobacco smoke, is also referred to as secondhand smoke (EPA, 2005; USDHHS, 2006). Cigarette smoke is a complex colloidal mixture containing well over 4,000 chemicals (EPA, 1992). Nicotine is probably the most thoroughly studied bioreactive chemical in cigarette smoke (Benowitz, 2008), but other chemicals that are known toxicants and carcinogens have likewise been studied (Hoffmann, Djordjevic \& Hoffmann, 1997; Jenkins, Guerin \& Tomkins, 2000). These include, for example, tar, heavy metals such as cadmium and lead, polycyclic hydrocarbons (PAHs), phenol, benzene, carbon monoxide, nitrosamines, and hydrogen cyanide. In addition, other chemicals that have not traditionally been recognized as toxic, such as pyridines, pyrazines, and phenols, have recently been shown in various biological assays to produce adverse effects at relatively low doses (Ji et al., 2002; Melkonian et al., 2003; Talbot \& Riveles, 2005). Given the complexity of the mixture of chemicals in burning tobacco, it is not surprising that most chemicals in smoke have not been studied thoroughly and the interaction of these chemicals is not well understood.

A number of epidemiological studies have shown that smoke exposure affects reproductive processes and that inhalation of either MS or SS smoke during pregnancy can cause adverse outcomes (Castles et al., 1999; DiFranza, Aligne \& Weitzman, 2004; Hegaard et al., 2006; Kharrazi et al., 2004;
Rogers, 2008; Stillman, Rosenberg \& Sachs, 1986). For example, the birth weight of fetuses born to mothers who smoke during pregnancy has repeatedly been shown to be lower than that of fetuses from non-smoking mothers (Rogers, 2008; Windham et al., 2000). Moreover, this relationship holds for in utero exposure to SS smoke, although the decrease in weight is not as great as for MS exposure (Goel et al., 2004; Windham et al., 2000). Other disturbing consequences of smoke exposure during pregnancy include increased incidences of ectopic implantation, stillbirth, structural malformations, and placental malfunction (Rogers, 2008; Saraiya et al., 1998; Shiverick \& Salafia, 1999). Additionally, offspring with normal appearance who have been exposed to smoke in utero may be victims after birth of sudden infant death syndrome, obesity, and decreased cognitive and respiratory development (Dwyer, Broide \& Leslie, 2008; Maritz, 2008; Rogers, 2008).

In spite of numerous epidemiological and animal studies done previously on smoking during pregnancy, we know relativity little about how smoke affects the earliest stages of prenatal development. The purpose of this review is to consolidate recent information addressing the effects of cigarette smoke exposure on events beginning with ovulation of the oocyte and extending through blastocyst formation. We will include recent data obtained using embryonic stem cells as models for early stages of development.

\section{OVULATION THROUGH FERTILIZATION}

Background: Ovulation and fertilization are complex processes requiring multiple steps that culminate in evacuation of the oocyte cumulus complex from the mature follicle 
and subsequent fusion of a sperm and oocyte (Richards, 2005; Talbot \& Riveles, 2005; Talbot, Shur \& Myles, 2003; Yanagimachi, 1984). Both ovulation and fertilization present a variety of potential targets for cigarette smoke. These targets include expansion of the oocyte cumulus complex, formation of a follicular rupture site, escape of the oocyte from the follicle, transport of the gametes to the ampulla of the oviduct where fertilization occurs, sperm penetration through the cumulus, sperm binding to the zona pellucida and induction of the acrosome reaction, sperm penetration of the zona pellucida, and gamete membrane fusion (Figure 1). The effects of cigarette smoke on some of these processes and the cells associated with them have been examined experimentally in animal systems, and additional insight has been gained through studies done at in vitro fertilization (IVF) clinics working with human gametes.

Cumulus expansion and ovulation: Following the Luteinizing Hormone (LH) surge, cumulus cells surrounding the maturing oocyte secrete a massive extracellular matrix that is rich in hyaluronic acid stabilized by cross-linked molecules of inter- $\alpha$-trypsin inhibitor (Chen et al., 1996). As the matrix hydrates, it causes the cumulus cells to move apart from each other, creating a large oocyte cumulus complex (OCC) that is ultimately ovulated from the mature follicle. This process, called cumulus expansion, facilitates the escape of the oocyte from the antrum of the follicle during ovulation (Talbot, 1983). The secreted matrix enables the OCC to stick to the surface of the infundibulum of the oviduct and then migrate into the ampulla, where fertilization occurs (Lam et al., 2000; Talbot, Gieske \& Knoll, 1999). Expansion also separates cumulus cells from each other clearing a pathway of low resistance through which sperm can penetrate and reach the zona pellucida (Talbot et al., 1985). The importance of the cumulus matrix cannot be overstated. Mice that are deficient in the matrix stabilizing proteins, inter- $\alpha$-trypsin inhibitor and tumor necrosis factorinduced protein-6, do not assemble functional matrices and are infertile (Fulop et al., 2003; Zhuo et al., 2001). Various studies have shown that the cumulus matrix is sensitive to the chemicals in cigarette smoke. Porcine oocyte cumulus complexes failed to expand properly when exposed in vitro to cadmium, anabasine, and nicotine (chemicals found in cigarette smoke), and additionally, nicotine and cadmium inhibited synthesis and assembly of hyaluronic acid, the major component of the cumulus matrix (Mlynarcikova et al., 2004; Vrsanska et al., 2003). In smokers, diminished functionality of the cumulus cells could be due to DNA damage which in patients undergoing IVF increases significantly in human cumulus cells from smokers vs. non-smokers (Sinko et al., 2005).

A defect in cumulus expansion could make evacuation of the antrum difficult and prevent some oocytes from escaping the follicle during ovulation (Talbot, 1983). Indeed, evidence from animal experiments indicates that the number of ovulating follicles decreases when exposed to smoke or smoke constituents. For example, hamsters that inhaled MS smoke for 30 days prior to and for the first 7 days during pregnancy showed a dose dependent decrease in the number of corpora lutea, indicating that ovulation was inhibited (Magers et al., 1995). Moreover, benzo(a)pyrene, a chemical in cigarette smoke, decreased the number of corpora lutea in pregnant mice (Swartz \& Mattison, 1985). In human IVF clinics, oocytes are normally aspirated, not ovulated from follicles. Nevertheless, in one study involving IVF patients, various parameters associated with ovulation were found to be adversely affected in smokers when compared to non-

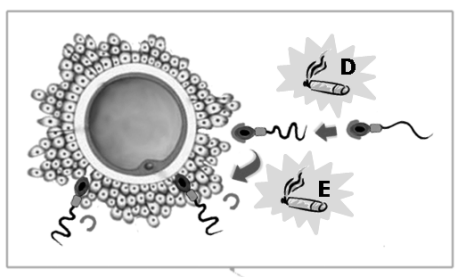

A) Cumulus Expansion

B) Ovulation

C) Oocyte Cumulus Complex Pick-up

D) Sperm Capacitation

E) Sperm Acrosome Reaction

F) Rate of Embryo Transport

G) Embryo Cell Division

H) Blastocyst Survival, Attachment, and Proliferation

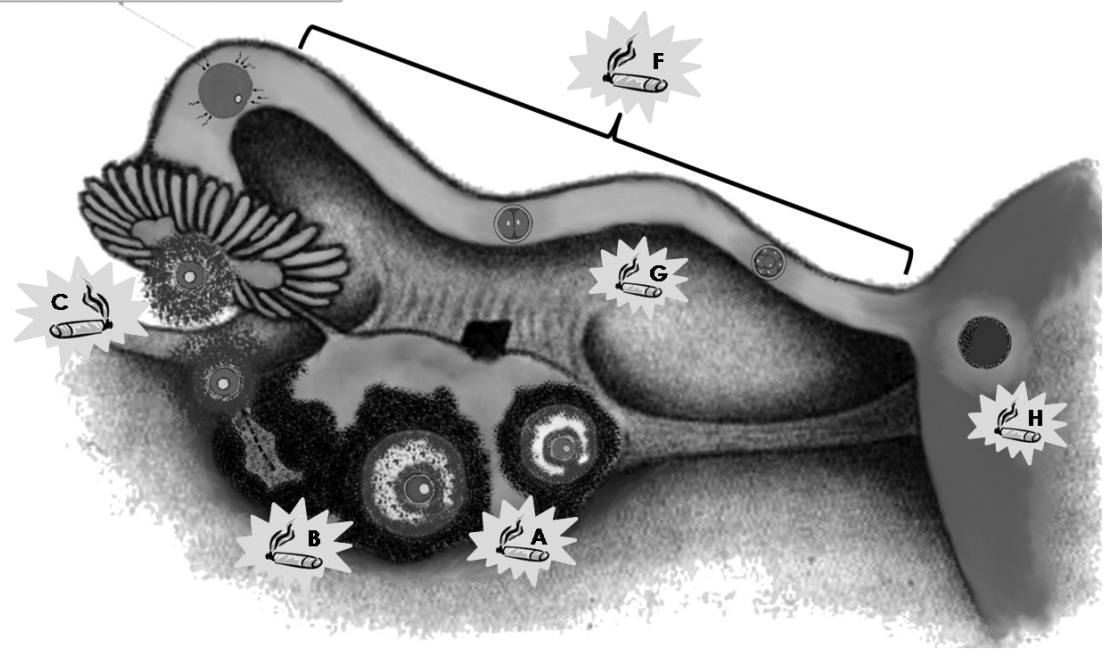

Figure 1: Schematic diagram showing the early developmental events that are affected by cigarette smoke. 
smoking controls (Van Voorhis et al., 1992). Defects in cumulus expansion coupled with difficulty in achieving ovulation could be factors contributing to the reported decrease in fertility among smokers (USDHHS, 2001).

OCC Transport into the Oviduct: OCC complexes, once released from the tertiary follicle, are picked up by the oviduct and rapidly transported into the ampulla by beating cilia on the outer surface of the infundibulum of the oviduct (Talbot \& Riveles, 2005). OCC pick-up requires adhesion between the tips of the cilia and the cumulus matrix, and factors that increase or decrease adhesion inhibit the rate of pick-up (Lam et al., 2000; Mahi-Brown \& Yanagimachi, 1983; Norwood \& Anderson, 1980). Inhalation of either MS or SS smoke prior to and during pregnancy increased the number of blebs on the oviductal epithelium of hamsters indicating smoke targets these cells (Magers et al., 1995). Both MS and SS smoke solutions inhibited ciliary beat frequency and oocyte pick-up rate in experiments using hamsters oviductal explants (Knoll \& Talbot, 1998). Fractionation and screening of smoke solutions using solid phase cartridges lead to the identification of about 30-40 chemicals that were inhibitory in the beat frequency and oocyte pick-up assays (Riveles et al., 2003; Riveles et al., 2004; Riveles, Roza \& Talbot, 2005). These chemicals were mainly pyridines, pyrazines, and phenols, and some were inhibitory at very low doses. Failure of the OCC to be picked up at the normal rate could lead to ectopic implantation, which increases significantly in smokers, or failure of fertilization. Pick-up rate was subsequently shown to be slowed in smoke treated groups because the components in smoke increased the adhesion between the cilia on the oviduct and the matrix between cumulus cells (Gieseke \& Talbot, 2005). The oviduct was further shown to be more seriously affected by smoke treatment than the OCC.

Fertilization: With the widespread use of in vitro fertilization (IVF) to treat infertility, the opportunities to collect data on reproductive processes surrounding fertilization are vast. Not surprisingly, numerous studies have been done in which various reproductive parameters including fertilization rate have been compared in smokers and non-smokers undergoing fertility treatment. Many of these studies have been recently examined in a meta-analysis (Waylen et al., 2009) and in several reviews (Cooper \& Moley, 2008; Soares \& Melo, 2008). While there is no consensus among these studies, some interesting trends are emerging. Soares and Melo (2008) concluded in their review that fertilization rate decreased in smokers, while Waylen et al (2009) concluded that fertilization rate was not different in most studies included in their metaanalysis. Since patients in IVF clinics are undergoing treatment for infertility, the non-smoking controls in these studies may not be robust enough to detect differences that would exist in the population at large or in a fertile population. In any case, very few IVF studies directly access the detailed events of fertilization, such as sperm penetration of the cumulus matrix, sperm binding to the zona pellucida, induction of the acrosome reaction, penetration of the zona, gamete membrane fusion, and establishment of blocks to polyspermy in the context of smoke exposure, and such studies would be difficult to perform in humans in vitro or in vivo.

Animal studies, which use controlled experimental conditions and eliminate confounding variables present in IVF work, have been done on some aspects of fertilization and provide insight into the effect of smoke on events leading to and including fertilization. Inhalation of cigarette smoke by rats for 10 weeks prior to performing in vitro fertilization decreased fertilization rates (Yamamoto et al., 1998). Although the specific cause of the problem was not determined in this study, fertilization was done in vitro suggesting that smoke exposure interfered with processes involved in fertilization and not factors involving the female reproductive tract (Yamamoto et al., 1998). Since nicotine and smoke exposure alter the properties of the cumulus matrix (Gieseke \& Talbot, 2005; Vrsanska et al., 2003), it is possible that sperm penetration through the cumulus is affected by smoking. Exposure of Rhesus monkey sperm to environmental tobacco smoke decreased their motility and ability to undergo hyperactivation when exposed to dbcAMP or caffeine (Hung et al., 2007). This could be due to damaged mitochondria in sperm treated with environmental tobacco smoke (Hung et al., 2007). In an interesting trial using patients undergoing in vitro fertilization, sperm from heavy smokers produced more female than male embryos, and this correlated with better performance of $X$ bearing sperm in the swim-up test, again suggesting that smoking affects sperm motility, which in turn affects sex ratio (Viloria et al., 2005).

Although acrosin levels in sperm from smokers and controls are not different, the inducibility of the human sperm acrosome reaction by ionophore A23187 is significantly lower in sperm from smokers than from fertile controls (El Mulla et al., 1995), which could impair sperm penetration through the zona and subsequent gamete membrane fusion. The difficulty in inducing acrosome reactions in smoker's sperm could be related to the level of calcium inside sperm. Calcium, which is required for induction of the acrosome reaction (Talbot et al., 2003), is reduced in boar sperm treated with the extractablerespirable particulates of environmental tobacco smoke (Zhou et al., 2000). Primate sperm treated with environmental tobacco smoke did not bind as well as untreated sperm to the zona pellucida (Hung et al., 2007). At the higher dose tested, a higher percentage of bound sperm was acrosome reacted, which could be due to induction of "false" acrosome reactions by toxic levels of smoke treated medium. The zona pellucida in both active and passive human smokers is significantly thicker than in non-smokers (Shiloh et al., 2004). Although not yet directly investigated, this increase in zona thickness could retard sperm penetration and decrease fertilization rate.

\section{PREIMPLANTATION DEVELOPMENT}

Animal studies on embryo movement though the oviduct: Movement of preimplantation embryos through the oviduct occurs in a precisely timed manner. Anything that alters the rate of transport can present complications to the establishment of a normal pregnancy. Moving too quickly could result in expulsion of the embryo from the female tract prior to implantation, while retarded movement may result in implantation in an ectopic site. Animal studies have shown that inhalation of either MS or SS smoke retards movement of hamster preimplantation embryos through the oviduct (DiCarlantonio \& Talbot, 1999). The doses that were effective in this study are similar to those found in human smokers based on measured values of cotinine in the serum of exposed hamsters. Moreover, the reduction in transport rate of the preimplantation embryos was correlated with decreased rates of contraction of the oviduct smooth muscle, suggesting that 
smoke exposure reduces muscle contractions thereby slowing transport rate. Nicotine alters the contractility of primate oviducts and may be one of the active factors in smoke that affects oviductal contractility (Neri \& Marcus, 1972). The well documented increase in ectopic pregnancy occurring in women who smoke during pregnancy could be related to a decrease in embryo transport rate through the oviduct (Handler et al., 1989; Saraiya et al., 1998).

Studies Using Embryonic Stem Cells (ESC): Embryos and fetuses are generally more sensitive to environmental toxicants than adults. In 2007, toxicologists released the Faroes Statement emphasizing the importance of studying prenatal development when evaluating environmental toxicants and drugs due to the likelihood that these stages will be the most sensitive of the entire life cycle (Grandjean et al., 2007). However, relatively little is known about the direct effects of environmental toxicants on early human pre-implantation embryos due to the ethical limitations of using human embryos for testing. Most prenatal toxicological studies have been done with animal models such as mice and rats, which have served us well, but which may not respond similarly to humans. Recently, toxicologists have turned to embryonic stem cells (ESC) as models for prenatal development. Pluripotent ESC, which are derived from the inner cell mass of blastocysts (Martin, 1981; Thomson et al., 1998), self-renew indefinitely, and have the ability to produce daughter cells that can differentiate into all the cells of an embryo. Thus embryonic stem cells themselves model the very young embryo, while embryonic stem cells, which differentiate, model later stages of prenatal development. The most thoroughly developed model based on embryonic stem cells and the only one that has been validated is the "embryonic stem cell test" developed in Europe (Chapin et al., 2008; Croxatto \& Villalón, 1994; Dávila et al., 2004). While originally based on differentiation of contracting cardiomyocytes, this assay has undergone continual improvements to include molecular endpoints (Seiler et al., 2004; zur Nieden, Kempka \& Ahr, 2004) and also to reduce the time required to perform the assay (Buesen et al., 2009). However, the "embryonic stem cell test" has not yet been adapted to hESC, and species variations in response to toxicants and the accuracy of its predictivity are of concern and can result in incorrect classification of substances.

Undifferentiated embryonic stem cells per se have recently been used by several labs to model early embryonic development in studies involving cigarette smoke or nicotine. In a study using mESC, nicotine doses that bracketed those in human smokers were found using quantitative RT-PCR to increase expression of Oct- 4 and Rex-1, two genes associated with pluripotency (Zhang et al., 2005). This effect could be prevented by tubocurarine, a nicotinic acetylcholine receptor antagonist. In a more recent study involving hESC, nicotine, again at doses that would be found in the reproductive tract of women who smoke during pregnancy, affected various endpoints (Zdravkovic et al., 2008). Nicotine inhibited adhesion of human ESC to extracellular matrix (Matrigel), an effect that was also blocked by tubocurarine. Moreover, nicotine treatment may have blocked attachment of suspended cells by interfering with integrin $\alpha 5 / \beta 1$, which was reduced in suspended cells treated with nicotine. Treated cells also had numerous small cytoplasmic vacuoles that disappeared when nicotine was washed out. A higher percentage of both attached and unattached hESC underwent apoptosis when treated with nicotine than when incubated in control medium, and this effect was reversed by tubocurarine in the unattached population. Induction of apoptosis by nicotine had been observed previously in post-implantation mouse embryos that were cultured and exposed to nicotine in vitro (Zhao \& Reece, 2005). In addition to nicotine, a PAH in cigarette smoke (7,12-dimethylben anthracene or DMBA) produces apoptosis in pre-implantation mouse embryos (Detmar et al., 2006), indicating that multiple chemicals in the complex milieu of cigarette smoke may be inducers of apoptosis in the early phase of development. The effect of nicotine on expression of pluripotency markers is not yet clear. In contrast to the study using mESC (Zhang et al., 2005), hESC pluripotency markers appeared to decrease when cells were exposed to nicotine (Zdravkovic et al., 2008). The reason for this discrepancy is not known, but could be due to species differences (mESC vs. hESC) or culture conditions (mESC experiments were done on feeder layers while those with hESC were done directly on Matrigel). Overall, nicotine affects a number of processes in hESC, and the reversibility of some of these effects by tubocurarine suggests that hESC have a receptor for nicotine.

In addition to nicotine, smoke solutions from various commercial cigarettes have been tested for their effects on mESC attachment to gelatin, proliferation, survival, and apoptosis (Lin, Tran \& Talbot, 2009). In this study, the toxicity of MS and SS smoke from traditional and harm reduction cigarettes was compared. Attachment and proliferation of ESC were inhibited dose dependently by treatment with MS or SS smoke solutions. On a puff for puff basis, SS smoke was more inhibitory in these assays than MS smoke. However, removing the filter from MS smoke increased its inhibitory effects significantly. Unexpectedly, in most assays, SS smoke from harm reduction brands (Marlboro Lights, Advanced Lights, and Quest) was more potent than SS smoke from the traditional brand (Marlboro Red), indicating the need for further evaluation of smoke from harm reduction products. Detection of activated caspases confirmed that smoke from all cigarette brands induced apoptosis in ESC populations. The results of the ESC assays were verified with actual mouse preimplantation embryos. Activated caspase 3 and 7 were detected in blastomeres of young mouse embryos after smoke treatment for 1 hour, demonstrating apoptotic activity within the inner cell mass.

Survival, attachment, proliferation, and apoptosis are important processes necessary for normal prenatal development. In the above studies with stem cells, attachment to a protein substrate (gelatin or Matrigel) was inhibited by whole smoke solutions (mESC) or by nicotine (hESC). Failure of cells to attach to extracellular matrices during early embryonic development could compromise subsequent steps in development, such as germ layer formation. Survival and proliferation of inner cell mass cells are likewise critical for proper embryo and fetal growth. In the mouse and human ESC models, treatment with nicotine (human) or smoke solution (mouse) increased the number of apoptotic cells in culture. While apoptosis occurs normally during prenatal development, too much apoptosis can impair development, leading to congenital defects (Zhao \& Reece, 2005) or embryo death (Detmar et al., 2006). Having a lower number of viable cells in the inner cell mass could also ultimately lead to lower fetal birth weights, as are seen in pregnant women who smoke (Hegaard et al., 2006; Windham et al., 2000). The idea that 
smoking impairs fetal growth by acting at the preimplantation stage of development is further supported by an in vivo study in which inhalation of mainstream and sidestream smoke by mice, at levels simulating human exposure, during days 1-5 of pregnancy, was sufficient to significantly decrease birth weight (Esposito et al., 2008). Interestingly, smoke exposure during days 6-18 of pregnancy did not affect birth weight, further emphasizing the sensitivity of the preimplantation embryo to smoke. Taken together, current data support the idea that young embryos are adversely affected by exposure to cigarette smoke and that during pregnancy women should avoid smoke exposure.

\section{CONCLUSIONS}

Although relatively few studies have addressed the specific effects of smoke on the earliest stages of human reproduction, there is sufficient information in the literature to conclude that smoking adversely affects cumulus expansion, gamete transport, fertilization, and in pre-implantation development (Figure 1). These effects could hinder the establishment of pregnancies, e.g. due to decreasing fertilization rates and could also impair growth and development of embryos during and after implantation, e.g. by diminishing the number of cells contributing to the embryo. The use of hESC as models of preand post implantation development should help further clarify the precise effects of smoke exposure on prenatal development in humans and have the further bonus of minimizing animal usage and eliminating concern about inter-species differences.

\section{ACKNOWLEDGEMENTS}

We are grateful to the Tobacco-Related Disease Research Program in California and the Academic Senate for supporting some of the work included in this review.

\section{REFERENCES}

BENOWITZ N L (2008) Clinical pharmacology of nicotine: implications for understanding, preventing, and treating tobacco addiction. Clin Pharmacol Ther 83, 531-41.

BUESEN R, GENSCHOW E, SLAWIK B, VISAN A, SPIELMANN H, LUCH A, SEILER A (2009) Embryonic Stem Cell Test Remastered: Comparison between the Validated EST and the New Molecular FACS-EST for Assessing Developmental Toxicity In Vitro. Toxicol Sci 108, 389-400.

CASTLES A, ADAMS E K, MELVIN C L, KELSCH C, BOULTON M L (1999) Effects of smoking during pregnancy. Five meta-analyses. Am J Prev Med 16, 208-15.

CHAPIN R, AUGUSTINE-RAUCH K, BEYER B, DASTON G, FINNELL R, FLYNN T, HUNTER S, MIRKES P, O'SHEA K S, PIERSMA A, SANDLER D, VANPARYS P, VAN MAELE-FABRY G (2008) State of the art in developmental toxicity screening methods and a way forward: a meeting report addressing embryonic stem cells, whole embryo culture, and zebrafish. Birth Defects Res B Dev Reprod Toxicol 83, 446-56.

CHEN L, ZHANG H, POWERS R W, RUSSELL P T, LARSEN W J (1996) Covalent linkage between proteins of the inter-a-inhibitor family and hyaluronic acid is mediated by a factor produced by granulosa cells. J Biol Chem 27, 19409-19414.

COOPER A R, MOLEY K H (2008) Maternal tobacco use and its preimplantation effects on fertility: more reasons to stop smoking. Semin Reprod Med 26, 204-12.

CROXATTO H B, VILLALÓN M (1994) Oocyte Transport. In Cambridge Reviews in Human Reproduction: The Oocyte (ed. J. G. Grudzinskas, T. Chard, J. L. Simpson and J. Yovich), pp. 253-276. Cambridge University Press, Cambridge.

DÁVILA J C, CEZAR G G, THIEDE M, STROM S, MIKI T, TROSKO J (2004) Use and application of stem cells in toxicology. Toxicol Sci 79, 214-23.
DETMAR J, RABAGLINO T, TANIUCHI Y, OH J, ACTON B M, BENITO A, NÚÑEZ G, JURISICOVA A (2006) Embryonic loss due to exposure to polycyclic aromatic hydrocarbons is mediated by Bax. Apoptosis 11, 1413-25.

DICARLANTONIO G, TALBOT P (1999) Inhalation of mainstream and sidestream cigarette smoke retards embryo transport and slows muscle contraction in oviducts of hamsters (Mesocricetus auratus). Biol Reprod 61, 651-6.

DIFRANZA J R, ALIGNE C A, WEITZMAN M (2004) Prenatal and postnatal environmental tobacco smoke exposure and children's health. Pediatrics $113,1007-15$.

DWYER J B, BROIDE R S, LESLIE F M (2008) Nicotine and brain development. Birth Defects Res C Embryo Today 84, 30-44.

EL MULLA K F, KOHN F M, EL BEHEIRY A H, SCHILL W B (1995) The effect of smoking and varicocele on human sperm acrosin activity and acrosome reaction. Hum Reprod 10, 3190-4.

EPA (1992) EPA Report/600/6-90/006F: Respiratory health effects of passive smoking: lung cancer and other disorders, Washington, DC.

EPA C (2005) Proposed identification of environmental tobacco smoke as a toxic air contaminant. Part B: Health Effects. California Environmental Protection Agency, Office of Environmental Health Hazard Assessment, Sacramento.

ESPOSITO E R, HORN K H, GREENE R M, PISANO M M (2008) An animal model of cigarette smoke-induced in utero growth retardation. Toxicology 246, 193-202.

FULOP C, SZANTO S, MUKHOPADHYAY D, BARDOS T, KAMATH R V, RUGG M S, DAY A J, SALUSTRI A, HASCALL V C, GLANT T T, MIKECZ K (2003) Impaired cumulus mucification and female sterility in tumor necrosis factor-induced protein-6 deficient mice. Development 130, 2253-61.

GIESEKE C, TALBOT P (2005) Cigarette smoke inhibits hamster oocyte pickup by increasing adhesion between the oocyte cumulus complex and oviductal cilia. Biol Reprod 73, 443-51.

GOEL P, RADOTRA A, SINGH I, AGGARWAL A, DUA D (2004) Effects of passive smoking on outcome in pregnancy. J Postgrad Med 50, 12-6.

HANDLER A, DAVIS F, FERRE C, YEKO T (1989). The relationship of smoking and ectopic pregnancy. Am J Public Health 79, 1239-42.

HEGAARD H K, KJAERGAARD H, MOLLER L F, WACHMANN H, OTTESEN B (2006). The effect of environmental tobacco smoke during pregnancy on birth weight. Acta Obstet Gynecol Scand 85, 675-81.

HOFFMANN D, DJORDJEVIC M V, HOFFMANN I (1997) The changing cigarette. Preventive Medicine 26, 437-434.

HUNG P H, BAUMBER J, MEYERS S A, VANDEVOORT C A (2007) Effects of environmental tobacco smoke in vitro on rhesus monkey sperm function. Reprod Toxicol 23, 499-506.

JENKINS R A, GUERIN M R, TOMKINS B A (2000) Mainstream and sidestream cigarette smoke. In Chemistry of Environmental Tobacco Smoke: Composition and Measurement, pp. 49-75. CRC Press, Boca Raton.

JI L, MELKONIAN G, RIVELES K, TALBOT P (2002) Identification of pyridine compounds in cigarette smoke solution that inhibit growth of the chick chorioallantoic membrane. Toxicol Sci 69, 217-25.

KHARRAZI M, DELORENZE G N, KAUFMAN F L, ESKENAZI B, BERNERT J T, JR GRAHAM S, PEARL M, PIRKLE J (2004) Environmental tobacco smoke and pregnancy outcome. Epidemiology $15,660-70$

KNOLL M, TALBOT P (1998) Cigarette smoke inhibits oocyte cumulus complex pick-up by the oviduct independent of ciliary beat frequency. Reproductive Toxicology 12, 57-68.

LAM X, GIESEKE C, KNOLL M, TALBOT P (2000) Assay and importance of adhesive interaction between hamster (Mesocricetus auratus) oocytecumulus complexes and the oviductal epithelium. Biol Reprod 62, 57988.

LIN S, TRAN V, TALBOT P (2009) Comparison of Toxicity of Smoke From Traditional and Harm Reduction Cigarettes Using Embryonic Stem Cells as a Novel Model for Pre-Implantation Development. Human Reproduction 24, 386-397.

MAGERS T, TALBOT P, DICARLANTONIO G, KNOLL M, DEMERS D, TSAI I, HOODBHOY T (1995). Cigarette smoke inhalation affects the reproductive system of female hamsters. Reprod Toxicol 9, 513-25.

MAHI-BROWN C A, YANAGIMACHI R (1983) Parameters influencing ovum pickup by oviductal fimbria in the golden hamster. Gam Res 8, $1-10$

MARITZ G S (2008) Nicotine and lung development. Birth Defects Res C Embryo Today $84,45-53$. 
MARTIN G R (1981) Isolation of a pluripotent cell line from early mouse embryos cultured in medium conditioned by teratocarcinoma stem cells. Proc Natl Acad Sci U S A 78, 7634-8.

MELKONIAN G, ECKELHOEFER H, WU M, WANG Y, TONG C, RIVELES K, P T (2003) Growth and angiogenesis are inhibited in vivo in developing tissues by pyrazine and its derivatives. Toxicological Sciences 75, 393-401.

MLYNARCIKOVA A, SCSUKOVA S, VRSANSKA S, NAGYOVA E, FICKOVA M, KOLENA J (2004) Inhibitory effect of cadmium and tobacco alkaloids on expansion of porcine oocyte-cumulus complexes. Cent Eur J Public Health 12 Suppl, S62-4.

NERI A, MARCUS S L (1972) Effect of nicotine on the motility of the oviducts in the Rhesus monkey: a preliminary report. J Reproduction Fertility 31, 91-.

NORWOOD J T, ANDERSON R G W (1980) Evidence that adhesive sites on the tips of oviduct cilia membranes are required for ovum pickup in situ. Biol Reprod 23, 788-791.

RICHARDS J S (2005) Ovulation: new factors that prepare the oocyte for fertilization. Mol Cell Endocrinol 234, 75-9.

RIVELES K, IV M, AREY J, TALBOT P (2003) Pyridines in cigarette smoke inhibit hamster oviductal functioning in picomolar doses. Reprod Toxicol 17, 191-202.

RIVELES K, ROZA R, AREY J, TALBOT P (2004) Pyrazine derivatives in cigarette smoke inhibit hamster oviductal functioning. Reprod Biol Endocrinol 2, 23.

RIVELES K, ROZA R, TALBOT P (2005) Phenols, quinolines, indoles, benzene, and 2-cyclopenten-1-ones are oviductal toxicants in cigarette smoke. Toxicol Sci 86, 141-51.

ROGERS J M (2008) Tobacco and pregnancy: overview of exposures and effects. Birth Defects Res C Embryo Today 84, 1-15.

SARAIYA M, BERG C J, KENDRICK J S, STRAUSS L T, ATRACH H K, AHN Y W (1998) Cigarette smoking as a risk factor for ectopic pregnancy. Am J Obstet Gynecol 178, 493-498.

SEILER, A, VISAN A, BUESEN R, GENSCHOW E, SPIELMANN H (2004) Improvement of an in vitro stem cell assay for developmental toxicity: the use of molecular endpoints in the embryonic stem cell test. Reprod Toxicol 18, 231-40.

SHILOH H, LAHAV-BARATZ S, KOIFMAN M, ISHAI D, BIDDER D, WEINER-MEGANZI Z, DIRNFELD M (2004) The impact of cigarette smoking on zona pellucida thickness of oocytes and embryos prior to transfer into the uterine cavity. Hum Reprod 19, 157-9.

SHIVERICK K T, SALAFIA C (1999) Cigarette smoking and pregnancy I: ovarian, uterine and placental effects. Placenta 20, 265-72.

SINKO I, MOROCZ M, ZADORI J, KOKAVSZKY K, RASKO I (2005) Effect of cigarette smoking on DNA damage of human cumulus cells analyzed by comet assay. Reprod Toxicol 20, 65-71.

SOARES S R, MELO M A (2008) Cigarette smoking and reproductive function. Curr Opin Obstet Gynecol 20, 281-91.

STILLMAN R J, ROSENBERG M J, SACHS B P (1986) Smoking and Reproduction. Fertil and Sterility 46, 545-566.

SWARTZ W J, MATTISON D R (1985) Benzo(a)pyrene inhibits ovulation in C57BL / 6N mice. Anat Rec 212, 268-276.

TALBOT P (1983) Intrafollicular pressure promotes partial evacuation of the antrum during hamster ovulation in vitro. J Exp Zool 226, 129-35.

TALBOT P, DICARLANTONIO G, ZAO P, PENKALA J, HAIMO LT (1985) Motile cells lacking hyaluronidase can penetrate the hamster oocyte cumulus complex. Dev Biol 108, 387-98.
TALBOT P, GIESKE C, KNOLL M (1999) Oocyte pickup by the mammalian oviduct. Mol Biol Cell 10, 5-8.

TALBOT P, RIVELES K (2005) Smoking and reproduction: the oviduct as a target of cigarette smoke. Reprod Biol Endocrinol 3, 52.

TALBOT P, SHUR B, MYLES D (2003) Cell adhesion and fertilization: steps in oocyte transport, sperm-zona pellucida interactions, and sperm-egg fusion. Biology of Reproduction 68, 1-9.

THOMSON JA, ITSKOVITZ-ELDOR J, SHAPIRO SS, WAKNITZ MA, SWIERGIEL JJ, MARSHALL VS, JONES JM (1998) Embryonic stem cell lines derived from human blastocysts. Science 282, 1145-7.

USDHHS (2001) Women and smoking: a report of the surgeon general. United States Department of Health and Human Services, Centers for Disease Control and Prevention, Office on Smoking and Health, Atlanta.

USDHHS (2006) The health consequences of involuntary exposure to tobacco smoke: a reprt of the surgeon general. United States Department of Health and Human Services, Centers for Disease Control and Prevention, Office on Smoking and Human Health, Atlanta.

VAN VOORHIS B J, SYROP C H, HAMMITT D G, DUNN M S, SNYDER G D (1992) Effects of smoking on ovulation induction for assisted reproductive techniques. Fertil Steril 58, 981-5.

VILORIA T, RUBIO M C, RODRIGO L, CALDERÓN G, MERCADER A, MATEU E, MESEGUER M, REMOHI J, PELliCER A (2005) Smoking habits of parents and male: female ratio in spermatozoa and preimplantation embryos. Hum Reprod 20, 2517-22.

VRSANSKA S, NAGYOVA E, MLYNARCIKOVA A, FICKOVA M, KOLENA J (2003) Components of cigarette smoke inhibit expansion of oocytecumulus complexes from porcine follicles. Physiol Res 52, 383-7.

WAYLEN A L, METWALLY M, JONES G L, WILKINSON A J, LEDGER W L (2009) Effects of cigarette smoking upon clinical outcomes of assisted reproduction: a meta-analysis. Hum Reprod Update 15, 31-44.

WINDHAM G C, HOPKINS B, FENSTER L, SWAN S H (2000) Prenatal active or passive tobacco smoke exposure and the risk of preterm delivery or low birth weight. Epidemiology 11, 427-33.

YAMAMOTO Y, ISOYAMA E, SOFIKITIS N, MIYAGAWA I (1998) Effects of smoking on testicular function and fertilizing potential in rats. Urol Res 26, 45-8.

YANAGIMACHI R (1984) Fertilization in mammals. Tokai J Exp Clin Med 9, 81-5.

ZDRAVKOVIC T, GENBACEV O, LAROCQUE N, MCMASTER M, FISHER S (2008) Human embryonic stem cells as a model system for studying the effects of smoke exposure on the embryo. Reprod Toxicol.

ZHANG H, GUO D, WANG L, ZHAO Y, CHENG Y, QIAO Z (2005) Effect of nicotine on Oct-4 and Rex-1 expression of mouse embryonic stem cells. Reprod Toxicol 19, 473-8.

ZHAO Z, REECE E A (2005) Nicotine-induced embryonic malformations mediated by apoptosis from increasing intracellular calcium and oxidative stress. Birth Defects Res B Dev Reprod Toxicol 74, 383-91.

ZHOU R, ZHOU Y, LI S, HAUG A (2000) Effect of environmental tobacco smoke on intracellular free calcium of boar sperm incubated in seminal plasma. Toxicol Lett 114, 135-41.

ZHUO L, YONEDA M, ZHAO M, YINGSUNG W, YOSHIDA N, KITAGAWA Y, KAWAMURA K, SUZUKI T, KIMATA K (2001) Defect in SHAPhyaluronan complex causes severe female infertility. A study by inactivation of the bikunin gene in mice. J Biol Chem 276, 7693-6.

ZUR NIEDEN N I, KEMPKA G, AHR H J (2004) Molecular multiple endpoint embryonic stem cell test--a possible approach to test for the teratogenic potential of compounds. Toxicol Appl Pharmacol 194, $257-69$. 